\title{
The effect of saline water magnetization on physiological and agronomic traits of some bread wheat genotypes
}

\author{
A.A. Said ${ }^{1}$, M.H. Motawea ${ }^{1}$, Abdel-rahman A. Mustafa ${ }^{2}$ and Y. Fawzy ${ }^{1}$ \\ ${ }^{1}$ Agronomy Department, Faculty of Agriculture, Sohag University, Sohag, Egypt \\ ${ }^{2}$ Soil and Water Department, Faculty of Agriculture, Sohag University, Sohag, Egypt.
}

\begin{abstract}
The present work relates to estimate the effect of magnetically-treated saline water on physiological and agronomic traits of 22 bread wheat genotypes and to determine the changes in soil properties. Replicated pot experiments involving potable water, saline water (2500 and $5000 \mathrm{ppm})$ and magnetically treated (2500 and $5000 \mathrm{ppm}$ saline water) were conducted in greenhouse during 2017/2018 and 2018/2019 winter seasons at Faculty of Agriculture, Sohag University, Sohag, Egypt. The results indicated the magnetically treated 2500 and $5000 \mathrm{ppm}$ saline water had positive effects on chlorophyll concentration by $7.29 \%$ and $7.96 \%$ and canopy temperature by $-6.14 \%$ and $-3.93 \%$ when compared with 2500 and 5000 ppm saline water, respectively. Moreover, the percent of increase due to using 2500 and $5000 \mathrm{ppm}$ saline water treated with magnetic reached to 4.25 and $8.42 \%$ for plant height, 3.7 and $13.43 \%$ for number of spikes/plant, 1.43 and $4.09 \%$ for spike length, 15.42 and $16.55 \%$ for 100 kernel weight, 6.52 and $6.15 \%$ for biological yield/plant and 9.94 and $5.41 \%$ for grain yield/plant compared to irrigation with 2500 and $5000 \mathrm{ppm}$ saline water, respectively. Also, the mean values of soil soluble cations and anions were less in soil irrigated with treated magnetic water than that irrigated with untreated magnetic water (having salinity of 2500 and $5000 \mathrm{ppm}$ ). It could be conducted that the treated magnetic water could effectively increase the physiological and agronomic traits of bread wheat genotypes. But indeed, more studies are needed to declare the influence of magnetic water on other different crops.
\end{abstract}

Keywords: Magnetic water, saline water, physiological traits, agronomic traits, wheat.

\section{Introduction}

Wheat (Triticum aestivum L.) is an important tropical and subtropical grain providing calories and protein of the food. Most of Egypt has a hot sub-tropical desert climate. Great efforts of wheat breeders must be continuing to increase the productivity of wheat to meet the demands of a growing population in Egypt. So, we need to increase

\footnotetext{
*Corresponding author: A. Said

Email: tentawy@gmail.com

Received: October 23, 2020

Accepted: December 4, 2020

Published: December 9, 2020
}

the productivity of wheat by increase the area under cultivation. To do so, new reclaimed area may be cultivated. In fact, many of these new reclaimed lands are suffering from salinity in which high salinity water is present. Under these conditions, the production of wheat (Triticum aestivum L.) is restricted, it is considered a moderately salt-tolerant crop (Maas and Hoffman, 1977). Therefore, this stresses the need for appropriate strategies to conserve the water and at the same time 
increase the productivity of grain under these conditions.

There are many promise technologies are used for mitigating the salinity. One of this new technology is magnetized water. Magnetized water has two important properties the first one is to reduce the salinity in irrigation water and the second one is high leaching ability. So that it can be used for saline water and hence increase the area under cultivation is possible. Some gainful impacts of the magnetized water for enhances growth and yield crop suggested by Hozayn and Qados (2010 a, b) and Grewal and Maheshwari (2011). This technology is not destructive or harmful and can be used widely to treat irrigation water to overcome the problems related to saline water. The main aim of this review is to decide the changes in soil properties because of irrigation with magnetically treated $2500 \mathrm{ppm}$ and $5000 \mathrm{ppm}$ saline water and to examine the performance of magnetically treated $2500 \mathrm{ppm}$ and 5000 ppm saline water on physiological and agronomic traits in wheat plants under greenhouse condition.

\section{Material and methods}

Twenty-two wheat genotypes (Triticum aestivum L.) from diverse origin including 2 local varieties and 20 advanced lines were used in this study (Table 1). Two experiments were carried out at Faculty of Agriculture, Sohag University, Egypt, during 2017/2018 and 2018/2019 winter seasons. A complete randomized design (CRD) with three replications was used. Each replication consist of 6 grains were sown in $12 \mathrm{~kg}$ capacity plastic pot, containing a combination clay and sandy soil (2:1). The plastic pots were maintained in greenhouse under natural light. All pots were irrigated up to field capacity with potable water (having EC of 587 ppm, table 2) for 20 days after sowing. After that, five irrigation treatments (up to field capacity) were applied viz., potable water (as a control), 2500 (Saline 1) and 5000 ppm saline water (Saline 2), magnetically treated 2500 (MWT 1) and 5000 ppm saline water (MWT 2). The saline water used was prepared by adding weighted amounts of $\mathrm{NaCl}$ salt to potable water to accomplish required salinity levels.

To comprehend the impact of salinity levels on magnetically treated water, two salinity levels were utilized, 2500 and $5000 \mathrm{ppm}$. The irrigation water of various types was treated with a magnetic device before applying to the wheat plants. The irrigation water was magnetized by using one-inch magnetron (A100S magnetic device), contains two magnets. The device involved a $100 \mathrm{~mm}$ pipe section with its inside diameter $22 \mathrm{~mm}$. For the magnetic treatment of irrigation saline water, it was passed twice though the magnetic device at the flow rate of $10 \mathrm{~mL} / \mathrm{s}$, providing the water magnetic field exposure of around three seconds. The recommended fertilizers doses were given for each box.

Table 1: Pedigree and source of 22 bread wheat genotypes used in the study.

\begin{tabular}{|l|l|}
\hline Genotype & \multicolumn{1}{c|}{ Pedigree } \\
\hline $\begin{array}{l}\text { 20 advanced } \\
\text { wheat lines }\end{array}$ & $\begin{array}{l}\text { from the International Maize and Wheat Improvement Center (CIMMYT), } \\
\text { Genetic Resources Center. }\end{array}$ \\
\hline Sids 12 & $\begin{array}{l}\text { BUC//7C/ALD/5/MAYA74/ON//1160.147/3/BB/GLL/4/C } \\
\text { HAT"S"/6/MAYA/VUL//CMH74A.630/4*SXSD7096-4SD-1SD-1SD-0SD. }\end{array}$ \\
\hline Giza 168 & MIL/BUC//Seri CM93046-8M-0Y-0M-2Y-0B. \\
\hline
\end{tabular}


Table 2: Chemical parameters of the irrigation water

\begin{tabular}{|l|c|c|}
\hline Property & Unit & Value \\
\hline pH & $\ldots \ldots$ & 7.8 \\
\hline EC & $\mathrm{mgl}^{-1}$ & 587 \\
\hline Na & $\mathrm{mgl}^{-1}$ & 39.1 \\
\hline K & $\mathrm{mgl}^{-1}$ & 74.1 \\
\hline Ca & $\mathrm{mgl}^{-1}$ & 40 \\
\hline $\mathbf{M g}$ & $\mathrm{mgl}^{-1}$ & 16.8 \\
\hline $\mathbf{H C O} 3$ & $\mathrm{mgl}^{-1}$ & 103.7 \\
\hline Cl & $\mathrm{mgl}^{-1}$ & 39.05 \\
\hline SO4 $_{4}$ & $\mathrm{mgl}^{-1}$ & 230.4 \\
\hline
\end{tabular}

The following data were recorded: Specific leaf area (leaf area in $\mathrm{cm}^{2}$ produced $\mathrm{gm}^{-1}$ leaf dry weight plant $^{-1}$ ), chlorophyll concentration (mg $\mathrm{cm}^{-2}$ ) using SPAD chlorophyll meter, canopy temperature $\left({ }^{\circ} \mathrm{C}\right)$ using infrared thermometer, plant height $(\mathrm{cm})$, no. of spikes/plant, spike length $(\mathrm{cm}), 100$-kernel weight (gm), biological yield/plant (gm) and grain yield/plant (gm).

\section{Statistical analyses}

The combined analysis was performed on the recorded data of physiological and agronomic traits according to Gomez and Gomez (1994). means were compared by Least Significant Difference (LSD) at 5\% level of significant (Steel and Torrie, 1980).

\section{Soil analysis:}

Representative soil samples were collected and analyzed for different properties following the standard methods for determination as described by Page et al. (1982). The properties soil properties before cropping is shown in Table (3).

\section{Results and discussion}

\section{ANOVA}

Combined analysis of variance (Table 4) indicated highly significant differences among genotypes, treatments (potable water, 2500 ppm, 5000 ppm, magnetically treated $2500 \mathrm{ppm}$ and magnetically treated $5000 \mathrm{ppm}$ saline water treatments) and their interaction effects for all studied traits.

\section{Effects of magnetic water technology on soil properties:}

Magnetic water treatment doesn't change chemical characteristics of water. Notwithstanding, it changes physical characteristics and as indicated by some authors, magnetic fields have impact on decrease of surface tension, viscosity, zeta potential, solubility, and diffusion (Bogatin, 1999, Cho and Lee, 2005, Gang et al., 2012 and Chang and Weng, 2006). A comparison of concentrations of various ions between the soil irrigated with treated magnetic water and the other one that irrigated with untreated magnetic water are presented in Table 3. At the first glance of Figure (1), It can be notice that the mean values of soil soluble cations and anions were less in samples that irrigated with treated magnetic water than that irrigated with untreated magnetic water (having salinity of $2500 \mathrm{ppm}$ ). Also, this true 
as compared with control. Whereas there was an increase in the mean values of soil soluble cations and anions in samples that irrigated with water that contain 5000 ppm salinity as compared with control treatment. But the magnetic treatment of saline water $(5000$ ppm) decreased the mean values of soil soluble cations and anions in the tested samples. Similar outcomes were gotten during a field experiment (Mostafazadeh-Fard et al., 2011 and Hachicha et al., 2018).

A comparison between electrical conductivity of saturated soil paste (ECe) of soils that irrigated with treated magnetic water and that irrigated with untreated magnetic water clearly showed that the ECe value of first one was lower than the second ( Table 3 and Fig. 2). This is due to the high leaching efficiency of magnetic water as compared with normal water. In general, the three primary noticed impacts of magnetic treatment of saline water in soil are the removal of excess soluble salts, decreasing of $\mathrm{pH}$ values, and the dissolving of slightly soluble components such as phosphates, carbonates, and sulfates. Moreover, the magnetic treatment of saline irrigation water is supposedly a successful strategy for soil desalinization (Hilai and Hilai, 2000, Mostafazadeh-Fard et al., 2011 and Hachicha et al., 2018).

There was a significant decrease of the $\mathrm{pH}$ values in soil solution of treated magnetic water. This is due to the same reasons as mentioned above (Hachicha et al., 2018). As a result of the impact of magnetized water on salt filtering and dissolution of $\mathrm{CaCO} 3$, the calcium carbonates concentrations were decreased by applying the magnetic field on irrigation water. Similar results were obtained by Hachicha et al. (2018).

As seen in Figure (3), there was an increase in the availability of macronutrients in soil samples that irrigated with treated magnetic water. The results of the current study (Table
3) showed that an increase in soil available N, $\mathrm{P}$ and $\mathrm{K}$, especially under magnetically treated saline water irrigation, seems to have assumed some part in improving growth of wheat plants. Such effect of magnetic field might be because of weakness bonds between certain ions and thought to be a major factor influencing on their activity in soil and plant. This finding is highly agreement with the results found by (Hilal et al., 2002, Selim, 2008, Maheshwari and Grewal, 2009, Hilal et al., 2013 and Mohamed, 2013).

\section{Chlorophyll concentration}

In the Figure $(4, a)$ revealed that the average chlorophyll concentration for potable water, 2500 ppm, magnetically treated 2500 ppm, $5000 \mathrm{ppm}$ and magnetically treated $5000 \mathrm{ppm}$ saline water treatments were 55.68, 49.64, 53.26, 45.10 and $48.69 \mathrm{mg} \mathrm{cm}^{-2}$. There was significant increase in chlorophyll concentration by applying magnetically treated $2500 \mathrm{ppm}$ saline water $(7.29 \%)$ and magnetically treated $5000 \mathrm{ppm}$ saline water (7.96\%) when compared with the saline 1 and 2 treatments, respectively in both seasons (Table 4). Tian et al. (1989), Atak et al. (2000 and 2003) and El Sayed (2014) who found an increase in plant chlorophyll content explicitly showed up after treat to a magnetic field.

\section{Canopy temperature}

For canopy temperature, overall genotypes, mean performance were $23.33,27.04,25.38$, 28.01 and $26.91{ }^{\circ} \mathrm{C}$ for control, Saline 1, MWT 1, Saline 2 and MWT 2 treatments (Fig. 4, b), respectively. In Table 5, the magnetically treated $2500 \mathrm{ppm}$ and $5000 \mathrm{ppm}$ saline water had significant effects on canopy temperature by $-6.14 \%$ and $-3.93 \%$ when compared with the saline 1 and 2 treatments, respectively. 
Table 3: Chemical characteristics of soil before and after cropping during 2017/2018 and 2018/2019.

\begin{tabular}{|c|c|c|c|c|c|c|c|c|c|c|c|}
\hline \multirow{4}{*}{ Property } & \multirow{4}{*}{ Unit } & \multicolumn{5}{|c|}{ Value (2017/2018) } & \multicolumn{5}{|c|}{ Value (2018/2019) } \\
\hline & & \multirow{3}{*}{$\begin{array}{c}\text { before } \\
\text { cropping }\end{array}$} & \multicolumn{4}{|c|}{ After cropping } & \multirow{3}{*}{$\begin{array}{c}\text { before } \\
\text { cropping }\end{array}$} & \multicolumn{4}{|c|}{ After cropping } \\
\hline & & & \multicolumn{2}{|c|}{$2500 \mathrm{ppm}$} & \multicolumn{2}{|c|}{5000 ppm } & & \multicolumn{2}{|c|}{2500 ppm } & \multicolumn{2}{|c|}{5000 ppm } \\
\hline & & & Treated & Untreated & Treated & Untreated & & Treated & Untreated & Treated & Untreated \\
\hline pHe & $\ldots$ & 8.03 & 7.71 & 8.11 & 7.78 & 8.3 & 7.53 & 8.12 & 8.54 & 7.78 & 8.19 \\
\hline $\mathbf{E C}_{\mathrm{e}}$ & $\mathrm{dSm}^{-1}$ & 1.89 & 1.05 & 3.21 & 3.8 & 5.69 & 1.77 & 1.11 & 3.38 & 4 & 5.33 \\
\hline $\mathrm{Ca}^{2+}$ & $\mathrm{mgl}^{-1}$ & 200 & 114.29 & 340 & 402 & 602 & 187.5 & 120.31 & 357.89 & 423.16 & 564.38 \\
\hline $\mathrm{Mg}^{2+}$ & $\mathrm{mgl}^{-1}$ & 14.48 & 8.57 & 24.62 & 29.1 & 43.58 & 13.58 & 9.02 & 25.92 & 30.63 & 40.86 \\
\hline $\mathrm{Na}^{+}$ & $\mathrm{mgl}^{-1}$ & 137.14 & 76.19 & 233.14 & 275.65 & 412.79 & 128.57 & 80.2 & 245.41 & 290.16 & 386.99 \\
\hline $\mathbf{K}^{+}$ & $\mathrm{mgl}^{-1}$ & 28.57 & 19.05 & 48.57 & 57.43 & 86 & 26.78 & 20.05 & 51.13 & 60.45 & 80.63 \\
\hline $\mathrm{HCO}_{3}^{-}$ & $\mathrm{mgl}^{-1}$ & 161.9 & 80.95 & 275.23 & 325.42 & 487.32 & 151.78 & 85.21 & 289.72 & 342.55 & 456.86 \\
\hline $\mathrm{Cl}^{-}$ & $\mathrm{mgl}^{-1}$ & 323.81 & 183.81 & 550.48 & 650.86 & 974.67 & 303.57 & 193.48 & 579.45 & 685.12 & 913.75 \\
\hline $\mathrm{SO}_{4}^{-2}$ & $\mathrm{mgl}$ & 334.29 & 185.71 & 568.29 & 671.92 & 1006.21 & 313.4 & 195.48 & 598.2 & 707.28 & 943.32 \\
\hline Available N & ppm & 556.19 & 945.52 & 640 & 970.45 & 668.71 & 521.43 & 995.28 & 673.68 & 1021.53 & 626.92 \\
\hline Available $P$ & ppm & 23.81 & 40.48 & 36.19 & 45.2 & 47.4 & 22.32 & 42.61 & 38.09 & 47.58 & 44.44 \\
\hline Available K & $\overline{\mathrm{ppm}}$ & 200 & 340 & 271.43 & 375.34 & 335.75 & 187.5 & 357.89 & 285.72 & 395.09 & 314.77 \\
\hline $\mathrm{CaCO}_{3}, \%$ & $\%$ & 0.69 & 0.41 & 0.83 & 0.54 & 0.55 & 0.9 & 0.54 & 1.09 & 0.71 & 0.72 \\
\hline Organic matter & $\%$ & 0.43 & 0.69 & 0.34 & 0.62 & 0.47 & 0.56 & 0.9 & 0.44 & 0.81 & 0.61 \\
\hline Field Capacity & $\%$ & 20 & 22 & 22 & 23 & 20 & 17 & 18 & 16 & 19 & 18 \\
\hline Wilting Point & $\%$ & 10 & 10 & 10 & 9 & 10 & 8 & 7 & 7 & 9 & 8 \\
\hline Water holding capacity & $\%$ & 10 & 12 & 12 & 14 & 10 & 9 & 11 & 9 & 10 & 10 \\
\hline Sand & $\%$ & 35.4 & 35.7 & 38.2 & 40.4 & 39.7 & 65.5 & 66.2 & 64.7 & 64.5 & 67.3 \\
\hline Silt & $\%$ & 27.8 & 27.3 & 23.1 & 26.8 & 24.8 & 4.1 & 3 & 2.6 & 3.8 & 1.9 \\
\hline Clay & $\%$ & 37.8 & 37 & 38.7 & 32.8 & 35.5 & 30.4 & 30.8 & 32.7 & 31.7 & 30.8 \\
\hline Texture class & & Clay loam & Clay loam & Clay loam & Clay loam & Clay loam & Clay loam & Clay loam & Clay loam & Clay loam & Clay loam \\
\hline
\end{tabular}




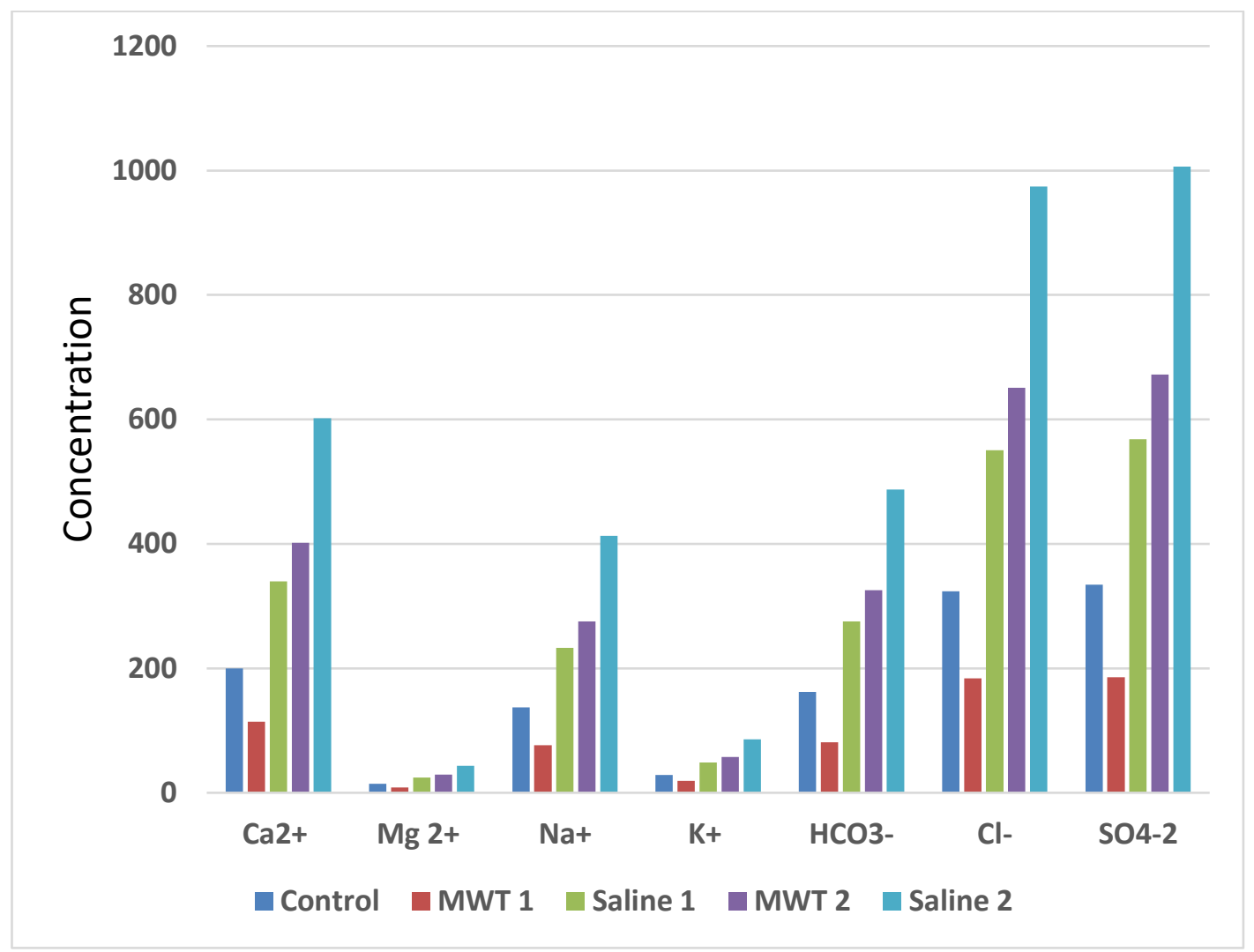

Fig. 1: The effect of magnetic treatments on soluble ions in the soil solution.

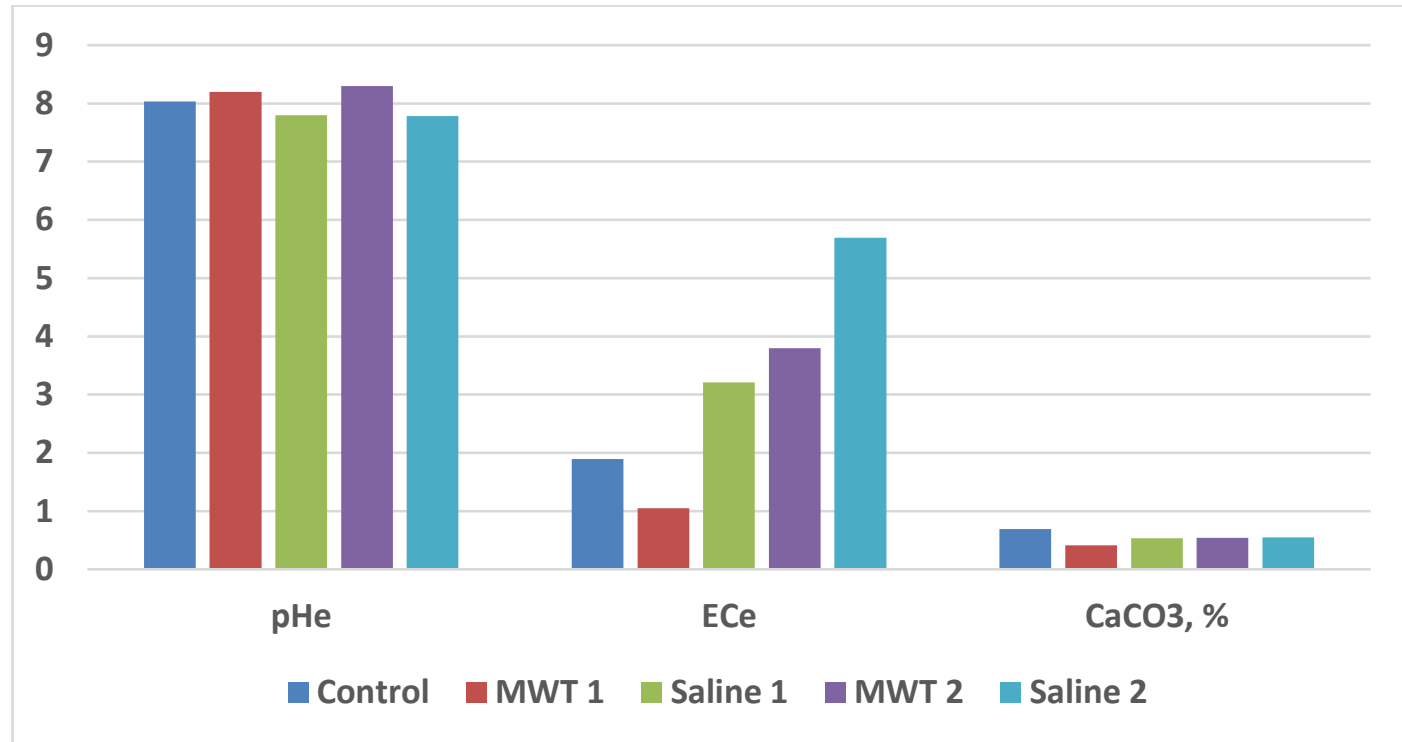

Fig. 2: The effect of magnetic treatments on $\mathrm{pH}, \mathrm{ECe}$ and $\mathrm{CaCO}_{3}$ in the soil. 
Table 4. Mean squares of the combined analysis of variance for all studied traits.

\begin{tabular}{|l|l|l|l|l|l|l|l|l|l|l|}
\hline \multirow{2}{*}{ S.o.v } & \multirow{2}{*}{ D.F } & \multicolumn{9}{|c|}{ Mean Squares } \\
\cline { 3 - 11 } & & $\begin{array}{c}\text { Plant } \\
\text { height }\end{array}$ & $\begin{array}{c}\text { Spike } \\
\text { length }\end{array}$ & $\begin{array}{c}\text { No. of } \\
\text { spikes } \\
\text { /plant }\end{array}$ & $\begin{array}{c}\text { Specific } \\
\text { leaf area }\end{array}$ & $\begin{array}{c}\text { Chlorophyll } \\
\text { content }\end{array}$ & $\begin{array}{c}\text { Canopy } \\
\text { temp. }\end{array}$ & $\begin{array}{c}\text { 1000- } \\
\text { kernel } \\
\text { weight }\end{array}$ & $\begin{array}{c}\text { Grain } \\
\text { yield / } \\
\text { plant }\end{array}$ & $\begin{array}{c}\text { Biological } \\
\text { yield/plant }\end{array}$ \\
\hline Year (Y) & 1 & $30142.84^{* *}$ & 0.088 & 0.076 & 40.95 & $1280.24^{* *}$ & $10947.15^{* *}$ & 0.111 & $30.64^{* *}$ & $282.91^{* *}$ \\
\hline Error a & 2 & 2.17 & 2.059 & 0.568 & 420.66 & 116.75 & 845.77 & 0.657 & 13.79 & 47.91 \\
\hline Treat. (T) & 4 & $4391.57^{* *}$ & $80.96^{* *}$ & $35.21^{* *}$ & $4663.97^{* *}$ & $2116.58^{* *}$ & $412.57^{* *}$ & $34.51^{* *}$ & $224.72^{* *}$ & $929.57^{* *}$ \\
\hline Y x T & 4 & $183.02^{* *}$ & $6.77^{* *}$ & $0.673^{*}$ & $215.88^{* *}$ & $110.58^{* *}$ & $43.09^{* *}$ & 0.049 & $6.96^{* *}$ & $160.39^{* *}$ \\
\hline Error b & 16 & 7.16 & 1.01 & 0.843 & 133.79 & 14.83 & 4.55 & $0.076^{* *}$ & 3.27 & 22.42 \\
\hline Genotype (G) & 21 & $311.24^{* *}$ & $40.54^{* *}$ & $7.52^{* *}$ & $1064.39^{* *}$ & $96.54^{* *}$ & $11.18^{* *}$ & $1.45^{* *}$ & $21.78^{* *}$ & $63.18^{* *}$ \\
\hline Y x G & 21 & $88.79^{* *}$ & 0.464 & 0.169 & 32.05 & $38.43^{* *}$ & $6.01^{* *}$ & 0.030 & $1.47^{* *}$ & $4.87^{* *}$ \\
\hline T x G & 84 & $50.27^{* *}$ & $0.997^{* *}$ & $0.672^{* *}$ & 56.10 & $32.33^{* *}$ & $7.38^{* *}$ & $0.554^{* *}$ & $5.02^{* *}$ & $21.71^{* *}$ \\
\hline Y x T x G & 84 & $38.83^{* *}$ & 0.446 & 0.125 & $71.02^{* *}$ & $15.23^{* *}$ & $3.45^{* *}$ & 0.032 & $1.23^{* *}$ & $3.95^{* *}$ \\
\hline Pooled error & 420 & 5.44 & 0.486 & 0.287 & 46.20 & 4.85 & 1.10 & 0.056 & 0.759 & 4.93 \\
\hline C.V. (\%) & & 3.27 & 6.68 & 13.29 & 6.24 & 4.34 & 4.01 & 11.40 & 15.13 & 12.15 \\
\hline
\end{tabular}

$* \& * *$ Significant at $5 \%$ and $1 \%$ levels of probability, respectively. 


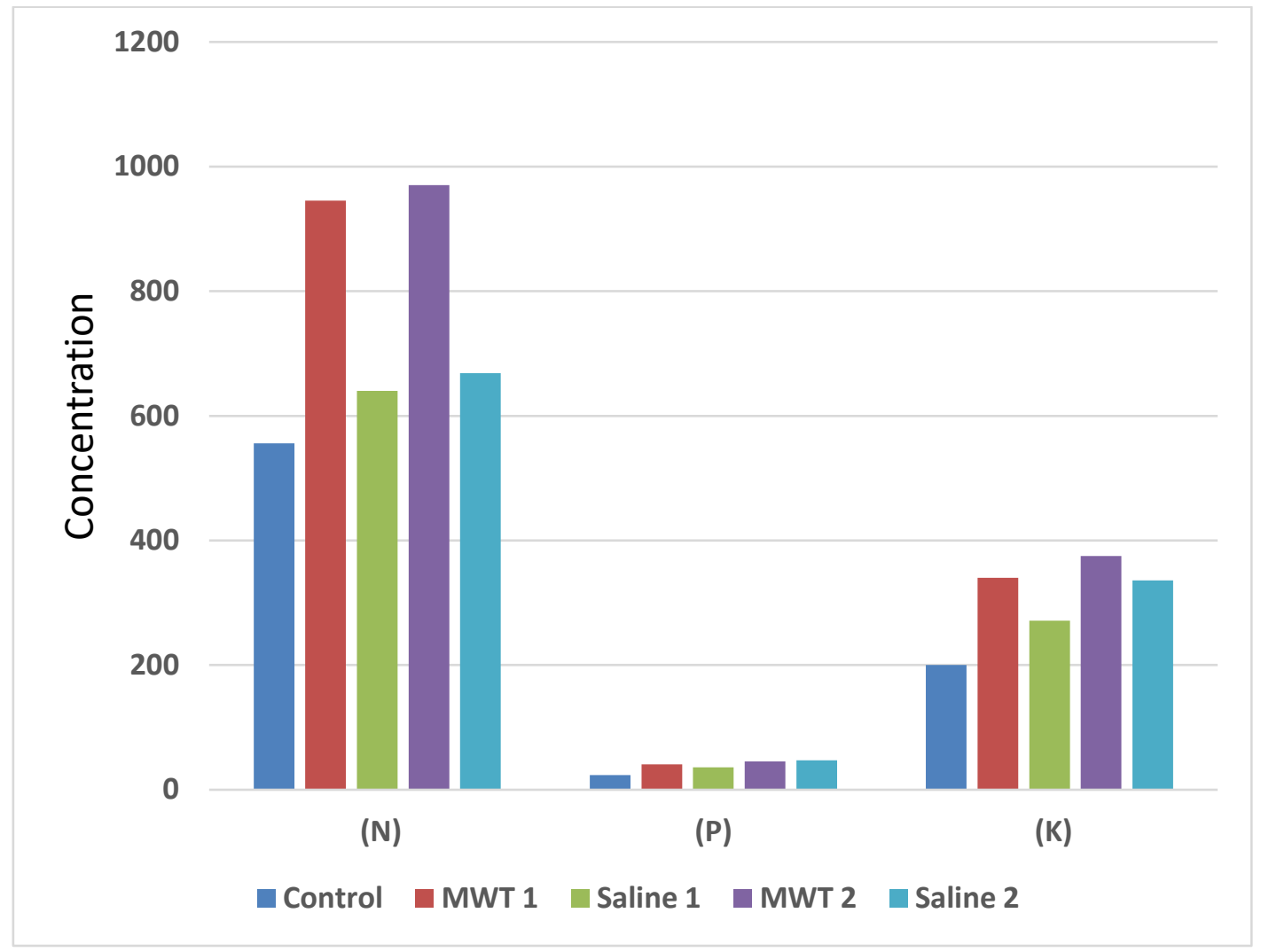

Fig. 3: The effect of magnetic treatments on available N, P and $\mathrm{K}$ in the soil.

\section{Effects of magnetic water} technology on wheat plants:

\subsection{Physiological traits:}

\section{Specific leaf area}

The average specific leaf area of wheat genotypes for control, Saline 1, MWT 1, Saline 2 and MWT 2 treatments (Fig. 4, c) over two seasons were 117.75, 108.90, $110.52,101.59$ and $102.24 \mathrm{~cm} \mathrm{gm}^{-1}$, respectively. So, irrigating wheat genotypes with magnetically treated $2500 \mathrm{ppm}$ and 5000 ppm saline water (Table 5) had nonsignificant increase specific leaf area by 1.49 $\%$ and $0.64 \%$ when compared with $2500 \mathrm{ppm}$ and $5000 \mathrm{ppm}$ saline water treatments, respectively. Sadeghipour, and Aghaei (2013) showed that magnetic water raised specific leaf area of cowpea plants than that the control.

\subsection{Agronomic traits:}

\section{Plant height}

The average plant height of 22 bread wheat genotypes for potable water (control), 2500

ppm (saline 1), magnetically treated 2500 ppm (MWT 1), 5000 ppm (saline 2) and magnetically treated $5000 \mathrm{ppm}$ (MWT 2) saline water treatments (Fig. 5, a) were 79.34, 70.65, 73.93, 63.78 and $69.15 \mathrm{~cm}$, respectively. Therefore, magnetically treated $2500 \mathrm{ppm}$ and $5000 \mathrm{ppm}$ saline water respectively (Table 5) resulted in $4.25 \%$ and $8.42 \%$ increase in plant height when compared to irrigation with $2500 \mathrm{ppm}$ and $5000 \mathrm{ppm}$ saline water in both seasons. These results agreement with that of De Souza et al. (2006) found positive outcomes of magnetized water on development of stem in wheat. In addition, Nasher (2008) revealed that chickpea plants irrigated with magnetic water were taller than plants irrigated with potable water. 


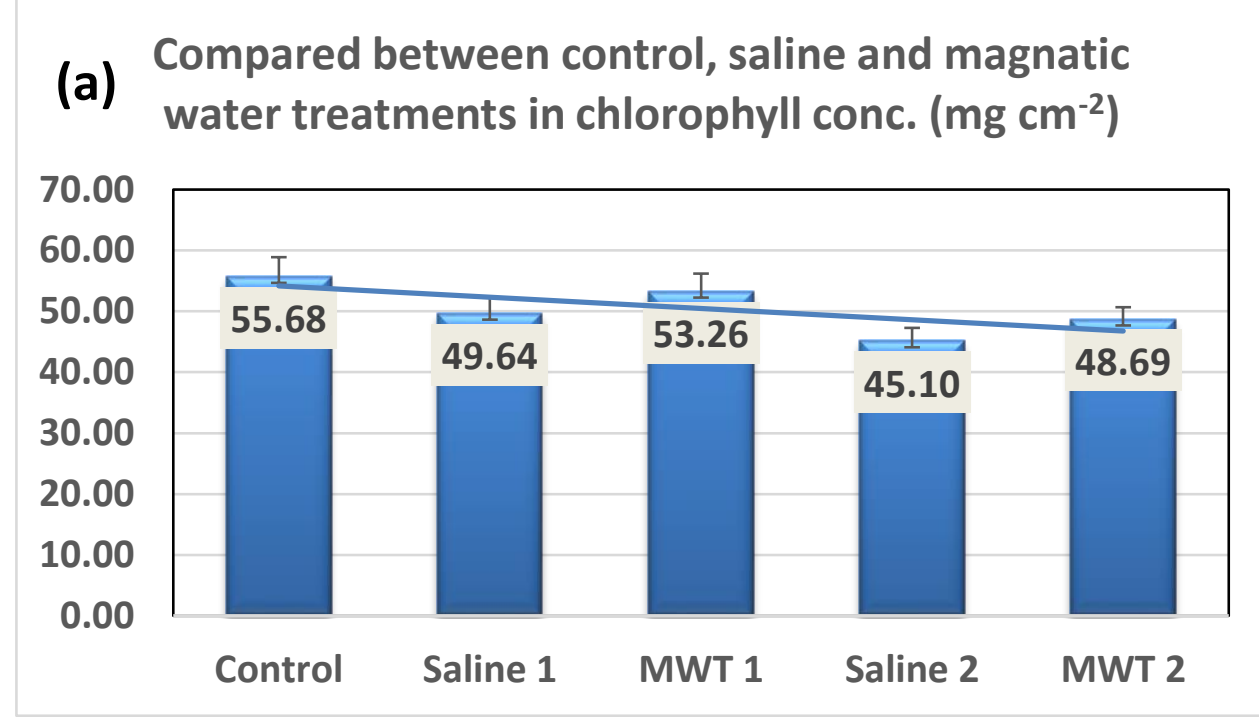

(b) Compared between control, saline and magnatic water treatments in canopy temperature $\left({ }^{\circ} \mathrm{C}\right)$

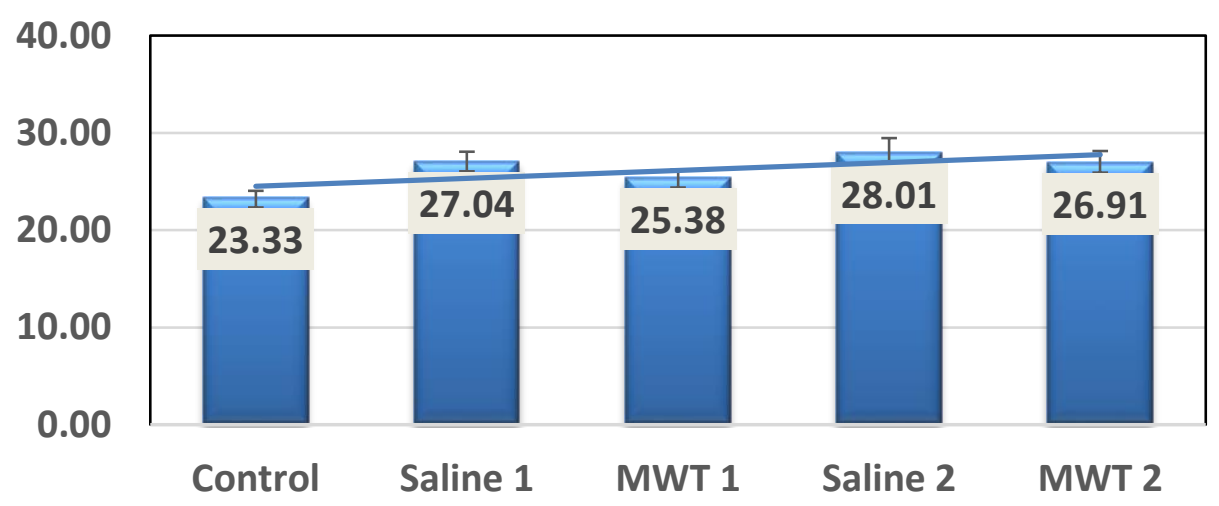

\section{(c) Compared between control, saline and magnatic c) water treatments in specific leaf area $\left(\mathrm{cm} \mathrm{gm}^{-1}\right)$}

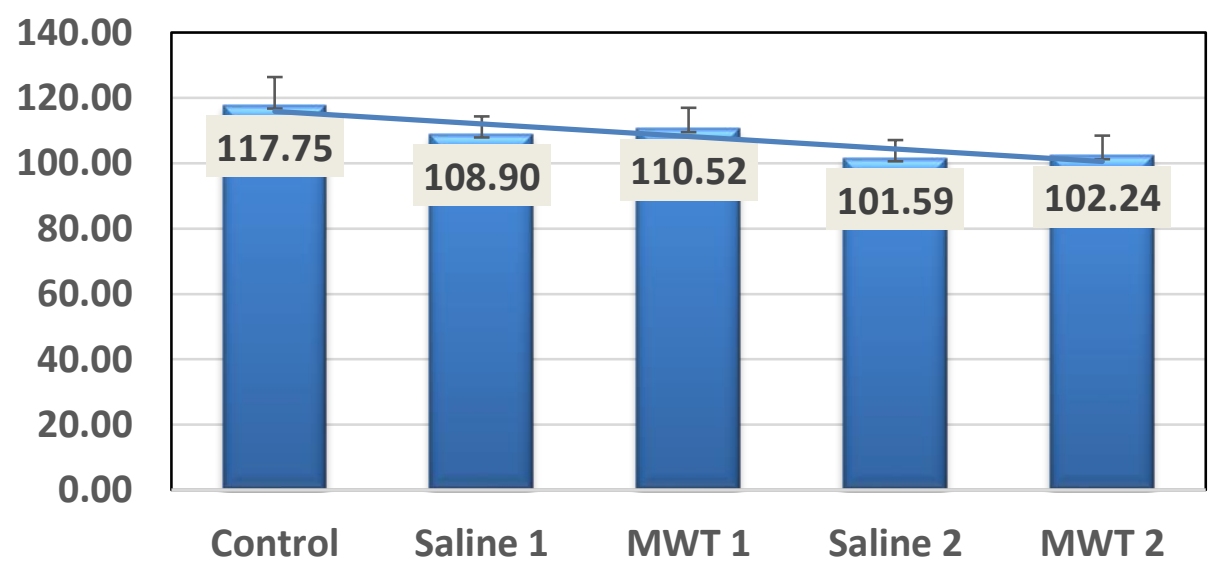

Figure 4 (a, b, and c): Chlorophyll concentration, canopy temperature and specific leaf area, of wheat genotypes grown under control, saline and magnetic water treatments. 
Table 5. Increased in overall mean of traits under magnetically treated when compared with saline water treatments.

\begin{tabular}{|c|c|c|c|c|c|c|c|c|}
\hline \multirow[t]{2}{*}{ Traits } & \multicolumn{3}{|c|}{ Mean over all genotypes } & \multirow{2}{*}{$\begin{array}{l}\text { increased } \\
\text { in trait } \\
(\%)\end{array}$} & \multicolumn{2}{|c|}{$\begin{array}{l}\text { Mean over all } \\
\text { genotypes }\end{array}$} & \multirow{2}{*}{$\begin{array}{c}\text { increased } \\
\text { in trait } \\
(\%)\end{array}$} & \multirow[t]{2}{*}{$\begin{array}{l}\text { LSD } 0.05 \\
\text { (Treatments) }\end{array}$} \\
\hline & Control & Saline 1 & MWT 1 & & Saline 2 & MWT 2 & & \\
\hline Plant height $(\mathrm{cm})$ & 79.34 & 70.65 & 73.65 & $4.25 \%$ & 63.78 & 69.15 & $8.42 \%$ & 0.565 \\
\hline Number of spikes/plant & 4.47 & 4.05 & 4.20 & $3.70 \%$ & 3.35 & 3.80 & $13.43 \%$ & 0.129 \\
\hline Spike length $(\mathrm{cm})$ & 11.59 & 10.53 & 10.68 & $1.43 \%$ & 9.53 & 9.92 & $4.09 \%$ & 0.169 \\
\hline 100 kernel weight (gm) & 2.73 & 2.10 & 2.42 & $15.24 \%$ & 1.45 & 1.69 & $16.55 \%$ & 0.057 \\
\hline Biological yield/plant (gm) & 21.83 & 18.55 & 19.76 & $6.52 \%$ & 15.13 & 16.06 & $6.15 \%$ & 0.537 \\
\hline Grain yield/plant (gm) & 7.87 & 5.62 & 6.18 & $9.94 \%$ & 4.44 & 4.68 & $5.41 \%$ & 0.211 \\
\hline Specific leaf area $\left(\mathrm{cm} \mathrm{gm}^{-1)}\right.$ & 117.75 & 108.90 & 110.52 & $1.49 \%$ & 101.59 & 102.24 & $0.64 \%$ & 1.65 \\
\hline Chlorophyll conc. $\left(\mathrm{mg} \mathrm{cm}^{-2}\right.$ ) & 55.68 & 49.64 & 53.26 & $7.29 \%$ & 45.10 & 48.69 & $7.69 \%$ & 0.533 \\
\hline Canopy temp. $\left({ }^{\circ} \mathrm{C}\right)$ & 23.33 & 27.04 & 25.38 & $-6.14 \%$ & 28.01 & 26.91 & $-3.93 \%$ & 0.254 \\
\hline
\end{tabular}


Table 6. Mean performance of grain yield/plant (gm) for wheat genotypes under control, saline and magnetic saline water treatments.

\begin{tabular}{|l|c|c|c|c|c|}
\hline Genotypes & Control & Saline 1 & MWT 1 & Saline 2 & MWT 2 \\
\hline Line 1 & 9.50 & 4.89 & 5.49 & 3.33 & 3.69 \\
\hline Line 2 & 10.84 & 5.56 & 6.42 & 3.39 & 3.45 \\
\hline Line 3 & 6.25 & 4.50 & 5.81 & 4.19 & 4.79 \\
\hline Line 4 & 7.88 & 5.12 & 5.64 & 3.36 & 2.64 \\
\hline Line 5 & 7.94 & 6.41 & 6.69 & 5.58 & 5.16 \\
\hline Line 6 & 5.43 & 5.08 & 5.30 & 4.25 & 4.42 \\
\hline Line 7 & 6.79 & 5.69 & 6.01 & 5.19 & 3.37 \\
\hline Line 8 & 5.73 & 3.35 & 4.47 & 1.96 & 3.76 \\
\hline Line 9 & 8.38 & 6.81 & 7.04 & 5.77 & 5.87 \\
\hline Line 10 & 5.67 & 4.33 & 4.99 & 4.02 & 3.55 \\
\hline Line 11 & 6.74 & 5.17 & 6.05 & 4.43 & 5.25 \\
\hline Line 12 & 7.79 & 5.96 & 6.48 & 5.45 & 5.86 \\
\hline Line 13 & 10.87 & 7.23 & 7.46 & 5.73 & 5.90 \\
\hline Line 14 & 7.23 & 5.81 & 6.45 & 4.19 & 5.23 \\
\hline Line 15 & 7.59 & 2.99 & 3.66 & 2.65 & 3.06 \\
\hline Line 16 & 9.36 & 6.97 & 7.73 & 4.19 & 4.44 \\
\hline Line 17 & 6.61 & 5.36 & 6.22 & 4.61 & 5.07 \\
\hline Line 18 & 7.07 & 6.51 & 6.53 & 5.55 & 5.29 \\
\hline Line 19 & 7.08 & 6.80 & 6.86 & 3.86 & 4.73 \\
\hline Line 20 & 8.95 & 6.44 & 6.76 & 5.86 & 6.10 \\
\hline Sids 12 & 9.58 & 6.36 & 7.01 & 5.04 & 5.76 \\
\hline Giza 168 & 9.94 & 6.18 & 6.93 & 5.18 & 5.53 \\
\hline Mean & $\mathbf{7 . 8 7}$ & $\mathbf{5 . 6 2}$ & $\mathbf{6 . 1 8}$ & $\mathbf{4 . 4 6}$ & $\mathbf{4 . 6 5}$ \\
\hline L.S.D 0.05 & 1.06 & 0.789 & 1.00 & 1.16 & 1.52 \\
\hline
\end{tabular}

\section{Number of spikes/plant}

Over all mean number of spikes per plant performance(Fig. 5, b) among potable water, $2500 \mathrm{ppm}$, magnetically treated $2500 \mathrm{ppm}$, $5000 \mathrm{ppm}$ and magnetically treated $5000 \mathrm{ppm}$ saline water treatments showed significant differences by 4.47, 4.05, 4.20, 3.35 and 3.80 spikes per plant, respectively. It is of interest to note that magnetically treated $2500 \mathrm{ppm}$ and $5000 \mathrm{ppm}$ saline water increased number of spikes per plant by $3.70 \%$ and $13.43 \%$, respectively as compared with $2500 \mathrm{ppm}$ and 5000 ppm saline water (Table 5). These results according to El Sayed (2014) indicated the positive effects of magnetic water on number of branches/plant of broad bean in compared to that of control. Hozayn et al. (2016) indicated that utilization of magnetizing irrigation water led to clear increases in branches (number plant ${ }^{-1}$ ) of Canola.

\section{Spike length}

The average spike length of wheat genotypes across control, Saline 1, MWT 1, Saline 2 and MWT 2 treatments (Fig. 5, c) in two seasons 
were $11.59,10.53,10.68,9.53$ and $9.92 \mathrm{~cm}$, respectively. Therefore, magnetically treated $2500 \mathrm{ppm}$ and $5000 \mathrm{ppm}$ saline water respectively resulted in $1.43 \%$ and $4.09 \%$ increase in spike length when compared to irrigation with $2500 \mathrm{ppm}$ and $5000 \mathrm{ppm}$ saline water (Table 5). These results are in good agreement with Alderfasi et al., (2016). Selim and Selim (2019) indicated that application of magnetic treatments caused significant increases in spike length of wheat plants.

\section{0 kernel weight}

On average over all genotypes, in 100-kearnel weight (Fig. 6, a) under control, Saline 1, MWT 1, Saline 2 and MWT 2 treatments were $2.73,2.10,2.42,1.45$ and $1.69 \mathrm{gm}$, respectively. For 100 kernel weight, there were $15.42 \%$ and $16.55 \%$ increases with magnetically treated $2500 \mathrm{ppm}$ and $5000 \mathrm{ppm}$ saline water, respectively (Table 5). The results are in harmony with those of Hozayn and Abdul Qados, (2010) who reported that magnetic water significantly increased seeds of chickpea plants in compared to that of control. In addition, El Sayed (2014) showed the positive impacts of magnetic water on weight of 100 seeds of broad bean as compared to the control treatment. Hozayn et al. (2016) reported that application of magnetizing irrigation water led to marked increases in 100- seed weight of Canola.

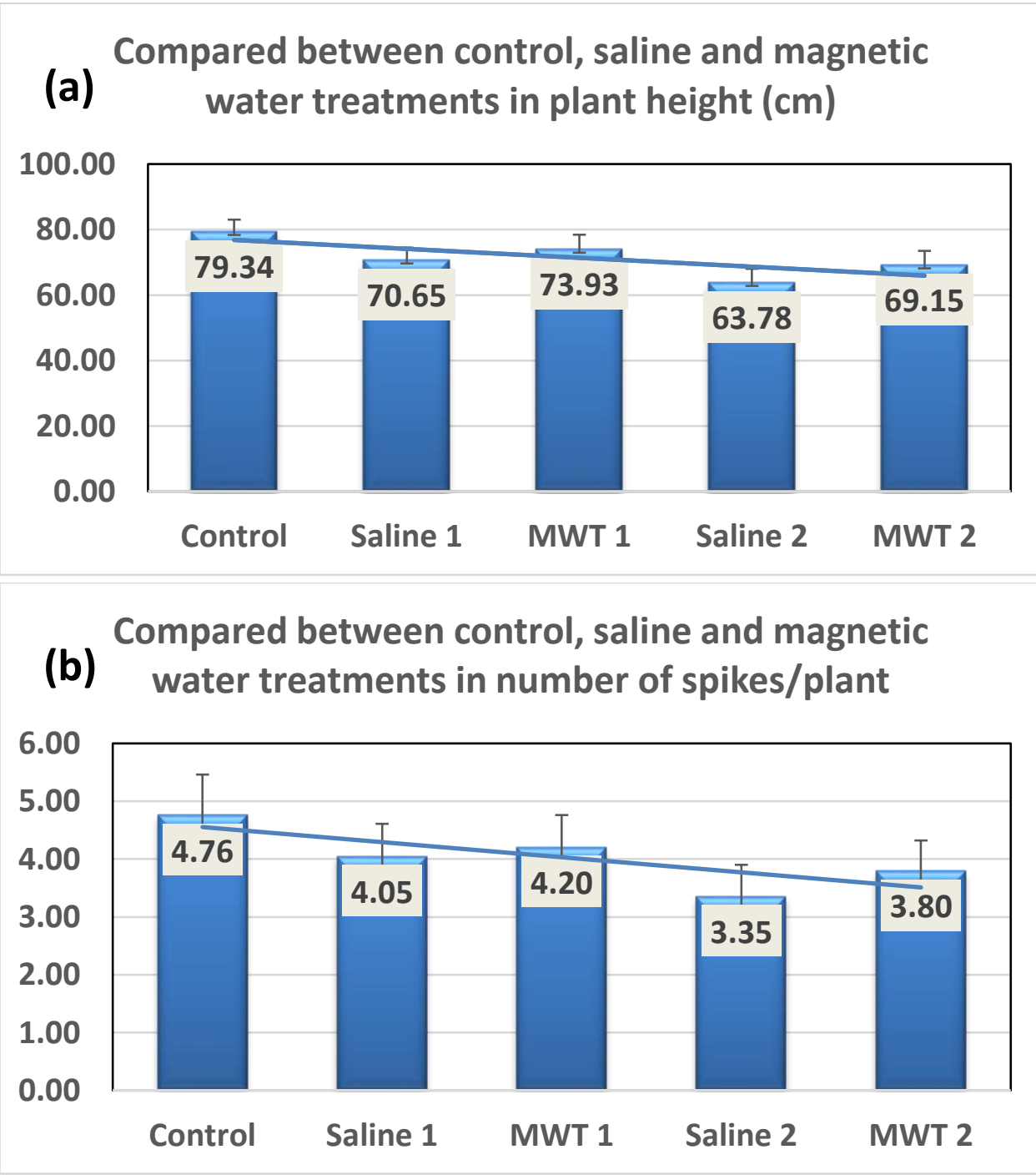




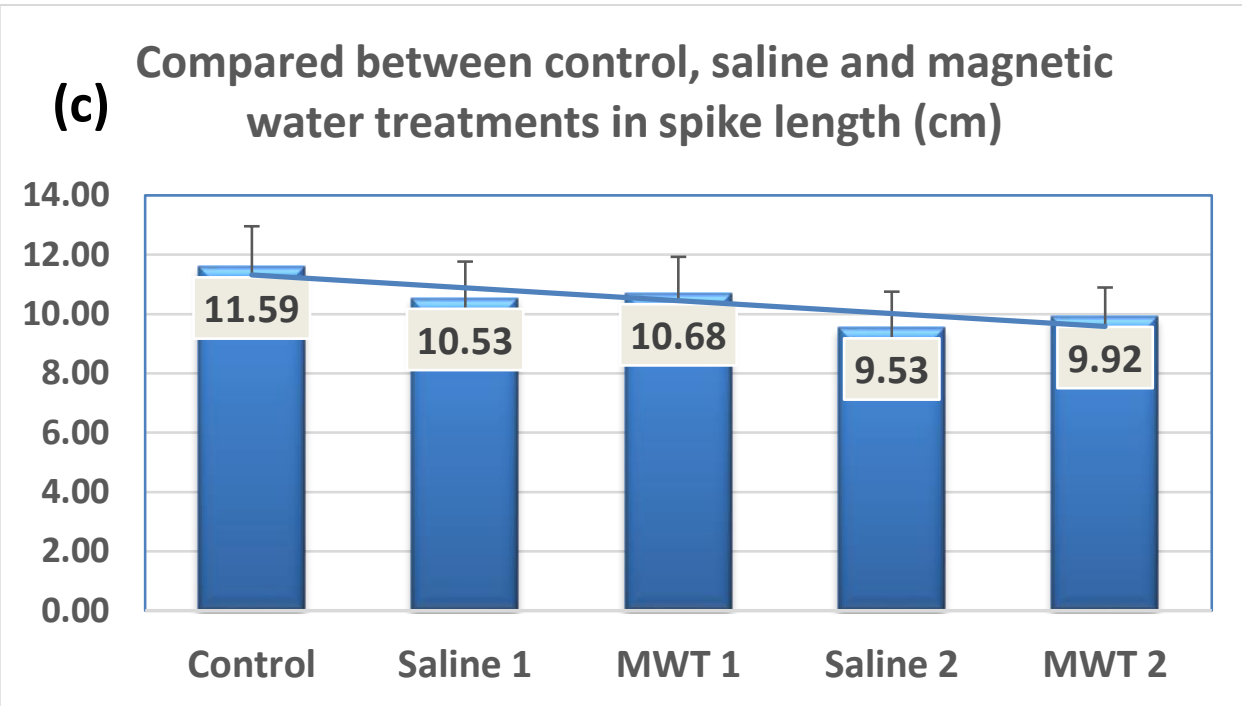

Figure 5 (a, b, and c): Plant height, number of spikes/plant and spike length of wheat genotypes grown under control, saline and magnetic water treatments.

\section{Biological yield/plant}

For means of biological yield/plant, the values recorded were $21.82,18.55,19.76,15.13$ and $16.06 \mathrm{gm}$ for control, Saline 1, MWT 1, Saline 2 and MWT 2 treatments, respectively. Furthermore, there was $6.52 \%$ and $6.15 \%$ increase in biological yield per plant by respectively applying magnetically treated $2500 \mathrm{ppm}$ and $5000 \mathrm{ppm}$ saline water when compared with the saline 1 and 2 treatments (Fig. 6, b and Table 5). These outcomes are in acceptable concurrence with El Sayed (2014) indicated the positive effects of magnetic water on straw yield/plant of broad bean. In addition, Magnetic water improved the biological yield of Canola plants (Hozayn et al., 2016).

\section{Grain yield per plant}

Data in Table (6) and Fig. $(6, \mathrm{c})$ indicated that mean grain yield per plant overall wheat genotypes for potable water (control), 2500 ppm (saline 1), magnetically treated 2500 ppm (MWT 1), 5000 ppm (saline 2) and magnetically treated $5000 \mathrm{ppm}$ (MWT 2) saline water treatments were 7.87, 5.62, 6.18, 4.44 and $4.68 \mathrm{gm}$, respectively in both seasons. However, there was significant differences between genotypes for grain yield by applying magnetically treated $2500 \mathrm{ppm}$ and $5000 \mathrm{ppm}$. Whereas the magnetic treatment of 2500 and 5000 ppm saline water increased grain yield by $9.94 \%$ and $5.41 \%$ when compared with $2500 \mathrm{ppm}$ and $5000 \mathrm{ppm}$ saline water treatments, respectively (Table 5). The irrigation of wheat plants with MWT caused significant enhancement in the grain yield per plant. These findings encourage the use of MWT for irrigation of wheat plants as environmentally friend tool enhance yield. The results are in harmony with those of Hilal and Helal (2003) who reported that the magnetically treated water has been used to improve yielding states of desert soils with high saltiness and calcification, where higher yields were acquired for wheat, tomato, maize and pepper. In addition, Selim (2008) showed that irrigation of lentil plant with magnetic treated water improves different crop yields for example, number of brunches and pods per plant and weight of pods. Likewise, Maheshwari (2009) indicated significant impacts of magnetically treated irrigation water on yield of pea and celery plants under irrigation with saline water conditions. 


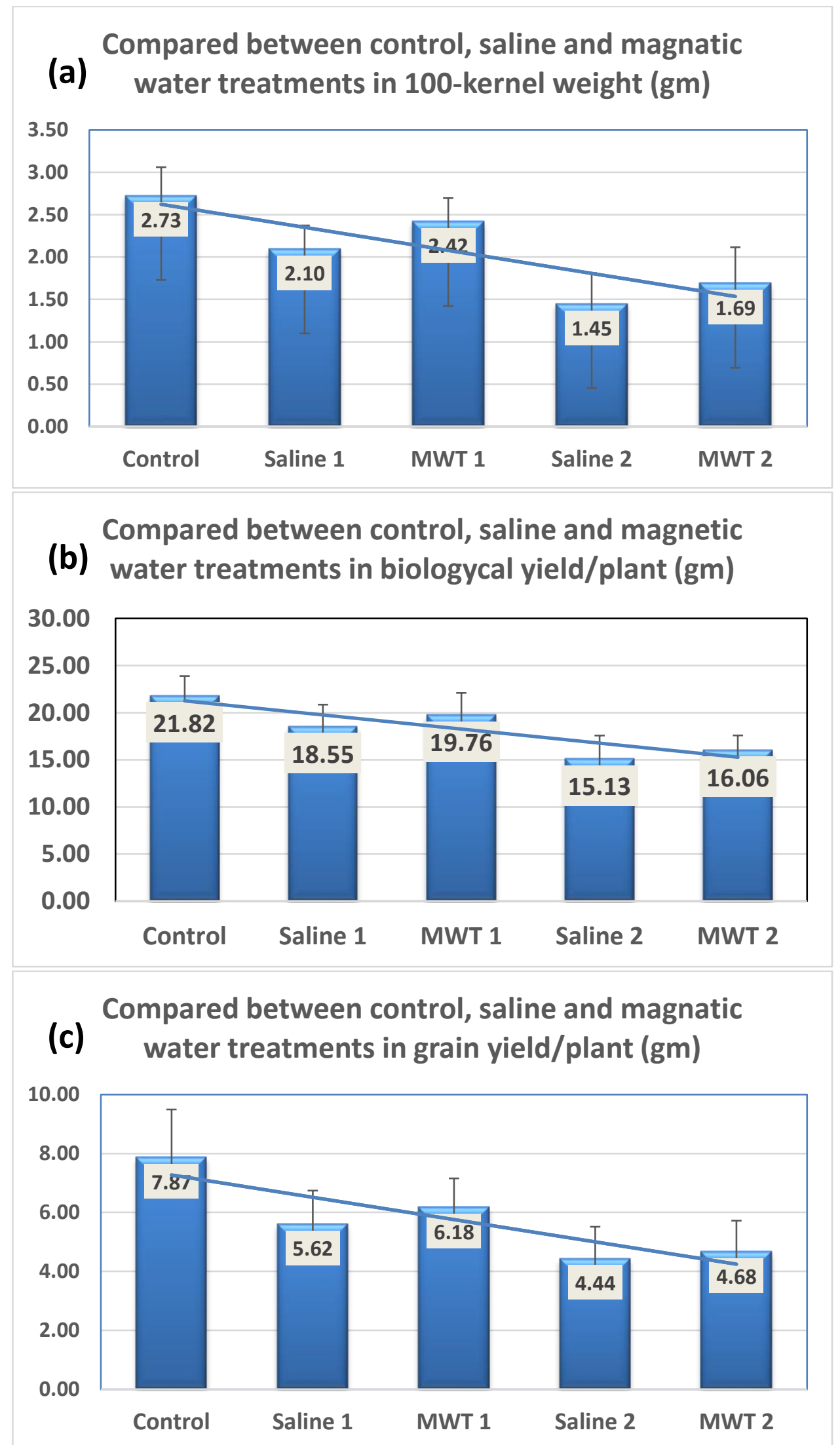

Figure 6 (a, b, and c): 100-kernel weight, biological yield/plant and grain yield/plant of wheat genotypes grown under control, saline and magnetic water treatments. 
In these studies the crop yield were increased significantly under magnetic irrigation (Reina et al., 2001, Takac et al., 2002, Marinkovic et al., 2002, Nasher, 2008, Hozayn and Abdul Qados, 2010,Hozayn et al., 2016,Ibrahim et al., 2016, Hachicha et al., 2018) and Selim and Selim (2019).

\section{Conclusions}

The magnetic treatment of irrigation water resulted in significant increases in the yield of bread wheat plants. It has additionally been seen that magnetically activated water utilized in agriculture helps for improvement of the physiological characters (chlorophyll concentration and canopy temperature), plant growth (plant height and biological yield/plant) and grain yield/plant and its components (spike length, number of spikes/plant and 100-kernel weight). Moreover, the mean values of soil soluble cations and anions were less that irrigated with treated magnetic water than that irrigated with untreated magnetic water (having salinity of 2500 and $5000 \mathrm{ppm}$ ). This also prevents from forming white salty deposits near the plant. Hence, the application of magnetic technology can be recommended for farmers, could be need for additional studies to overcome the field challenges and more information about the mechanism of action of the MWT that affect plant yield.

\section{Reference}

Alderfasi, A.A., Al-Suhaibani, N.A., Selim, M.M.,Al-Hammad, B.A.A. (2016) ' Using magnetic technologies in management of water irrigation programs under arid and semi-arid ecosystem', Adv. Plants Agric. Res.,3(4) pp.109-116.

Atak Ç., Danilov V., Yurttafl B., Yalçn S., Mutlu D. and Rzakoulieva A. (2000)
'Effect of magnetic field on Paulownia seeds', Com JINR. Dubna, pp. 1-14.

Atak C., Emiroglu O., Aklimanoglu S., and Rzakoulieva A. (2003) 'Stimulation of regeneration by magnetic field in soybean (Glycine $\max$ L. Merrill) tissue cultures', J. Cell Mol. Biol., (2) pp. 113-119.

Bogatin, J., Bondarenko, N. P., Gake, E. Z., Rokhinson, E. E., and Ananyev, I. P. (1999) 'Magnetic treatment of irrigation water: Experimental results and application conditions',Environ. Sci. Technol., 33 (8) pp. 1280-1285.

Chang, K., and Weng, C. (2006) 'The effect of an external magnetic field on the structure of liquid water using molecular dynamics simulation', Journal of Applied Physics, 100, 043917.

Cho,Y.I. and Lee,S. (2005) 'Reduction of the surface tension of water due to physical water treatment for fouling control in heat exchangers', International Communication in Heat and Mass Transfer, (32) pp. 1-9.

De Souza, A., Garci, D., Sueiro, L., Gilart, F., Porras, E. andLicea, L. (2006) 'Presowing magnetic treatments of tomato seeds increase the growth and yield of shoots', Bioelectromagnetics, (27) pp. 247- 257.

El Sayed, H. E. A. (2014) 'Impact of Magnetic Water Irrigation for Improve the Growth, Chemical Composition and Yield Production of Broad Bean (Vicia faba L.) Plant', American J. of Exp. Agri., 4(4) pp. 476-496.

Gang, N., St-Pierre, L.S. and Persinger, M.A. (2012) 'Water Dynamics Following Treatment by One Hour of 0.16 Tesla Static Magnetic Fields Depends on Exposure Volume', Water, (3) pp. 122-131. 
Gomez, K. A. and Gomez, A. A. (1984) 'Statistical Procedures for Agricultural Research', 2nd Ed., John Wiley and Sons, New York, USA.

Grewal, H.S. and Maheshwari, B.L. (2011)'Magnetic treatment of irrigation water and snow pea and chickpea seeds enhances early growth and nutrient contents of seedlings',Bioelectromagnetics,(32) pp. 58-65.

Hachicha M., Kahlaoui, B., Khamassi, N.,Misle, E. and Jouzdan, O. (2018) 'Effect of electromagnetic treatment of saline water on soil and crios', J. of the Saudi Society of Agr. Sci., (17) pp. 154-162.

Hilal, M. H., El-Fakhrani, Y. M., Mabrouk, S.S., Mohamed, A.I. and Ebead, B.M. (2013) 'Effect Of Magnetic Treated Irrigation Water On Salt Removal From A Sandy Soil And On The Availability Of Certain Nutrients', International Journal of Engineering and Applied Sciences, 2(2) pp. 36-44.

Hilal, M.H. and Hilal, M.M. (2000) 'Application of magnetic technologies in desert agriculture. II-Effect of magnetic treatments of irrigation water on water on salt distribution in olive and citrus field and induced changes of ionic balance in soil and plant',Egyptian Journal of Soil Science, 40 (3) pp. 423-435.

Hilal, M.H. and Helal, M.M. (2003)'Application of magnetic technologies in desert agriculture. Seed germination and seedling emergence of some crops in a saline calcareous soil. In: Proc. II Int', Conf. Impact of Electromagnetic Fields in the Agricultural Environment, Agrolaser, September 8-10, Lublin, Poland.
Hilal, M.H., Shata, A.A, Abdel-Dayem, and Hillal, M.M. (2002) 'Application of magnetic technologies in desert agriculture. III- Effect of Magnetized Water on yield and uptake of certain elements by citrus in relation to nutrients mobilization in soil',Egypt $J$. Soil Sci., 42(1) pp. 43-55.

Hozayn M., Abdallha, M. M., Abd El-Monem A. A., El-Saady, A. A.and Darwish M. A. (2016) 'Applications of magnetic technology in agriculture: A novel tool for improving crop productivity (1): Canola',Afr. J. Agric. Res., 11 (5) pp. 441-449.

Hozayn, M. and Abdul Qados, A. M. S. (2010) 'Irrigation with magnetized water enhances growth, chemical constituent and yield of chickpea', Agric. Biol. J. N. Am., 1 (4) pp. 671676.

Hozayn, M. and Qados, A.M.S.A. (2010a) 'Irrigation with magnetized water enhances growth, chemical constituent and yield of chickpea (Cicer arietinumL.)', Agriculture and Biology Journal of North America, 1 (4) pp. 671-676.

Hozayn, M. and Qados, A.M.S.A. (2010b) 'Magnetic water application for improving wheat (Triticum aestivumL.) crop production', Agriculture and Biology Journal of North America1(4) pp. 677-682.

Ibrahim I., Al-Mashhadani, H., Rasheed, Kh. A.,Ismail, E.N., Hassan, S. M. (2016) 'Effect of Magnetic Water Treatment on Salt Tolerance of Selected Wheat Cultivars', J. Int. Environmental Application \& Science, 11 (1) pp. 105109.

Maas, E.V., Hoffman, G.J. (1977)'Crop salt tolerance - current assessment', Journal of the Irrigation and 
Drainage Division of the American Society of Civil Engineering, (103) pp. $115-134$.

Maheshwari, B.L, and Grewal, H.S. (2009) 'Magnetic treatment of irrigation water: Its effects on vegetable crop yield and water productivity', Agric Water Manage (96) pp. 1229-1236.

Maheshwari, L. B., (2009) 'Magnetic treatment of irrigation water: evaluation of its effects on vegetable crop yield and water productivity',Ph.D Thesis. University of Western Sydney, School of Environ., and Agriculture, Australia

Marinkovic, B., Ilin, Z., Marinkovic, J., Culibrk, M. and Jacimovic, G. (2002) 'Potato yield in function variable electromagnetic field', Biophysics in agriculture production, University of Novi Sad, Tomograf.

Mohamed, A. I. (2013) 'Effects of magnetized low qualitywater on some soil properties and plant growth', International Journal of Research in Chemistry and Environment, 3 (2) pp. 140-147.

Mostafazadeh-Fard, B., Khoshravesh, M., Mousavi, S. F, and Kiani, A. R. (2011) 'Effects of magnetized water and irrigation water salinity on soil moisture distribution in trickle irrigation',J. Irrig. Drain. Eng., 137 (6) pp. 398-402.

Nasher, S. H. (2008) 'The Effect of magnetic water on growth of chickpea seeds',Eng. \& Tech., 26 (9):4 pages.

Page, A.L., R.H. Miller, and D.R. Keeney (1982) 'Methods of Soil Analysis'. Part 2: Chemical and Microbiological Analysis. Am. Soc., Madison, Wisconsin, USA.

Reina, F.G., Pascual, L.A. and Fundora, I.A. (2001)'Influence of a stationary magnetic field on water relations in lettuce seeds. Part II: Experimental Results', Bioelectromagnetics, (22) pp. 596-602.

Sadeghipour, O., and Aghaei, P. (2013) 'Improving the growth of cowpea (Vigna unguiculataL. Walp.) by magnetized water', J. Bio. \& Env. Sci., 3 (1) pp. 37-43.

Selim, A. H. and Selim, D. A. H. (2019) 'Physio-Biochemical behaviour, water use efficiency and productivity of wheat plants exposed to magnetic field', J. Plant Production, Mansoura Univ., 10 (2) pp. 185 - 191.

Selim, M.M. (2008) 'Application of Magnetic Technologies in Correcting Under Ground Brackish Water for Irrigation in the Arid and Semi-Arid Ecosystem', The 3rd International Conference on Water Resources and Arid Environments and the 1st Arab Water Forum.

Steel, R. G. D., and Torrie, J. H. (1980) 'Principles and Procedures of Statistics. McGraw Hill Book Company', Inc. New York.

Takac, A., Gvozdenovic, G. and Marinkovic, B. (2002) 'Effect of resonant impulse electromagnetic stimulation on yield of tomato and pepper', Biophysics in agriculture production, University of Novi Sad, Tampograf.

Tian, W. X., Kuang, Y. L., and Mei, Z. P. (1989) 'Effect of magnetic water on seed germination, seedling growth and grain yield of rice', J. Jilin Agric Univ., (11) pp. 11-6. 